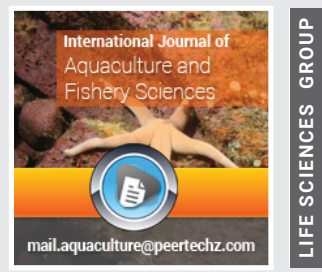

\title{
Diversity of fishes in Beles and Gilgel beles Rivers, abay basin, Ethiopia
}

\author{
Abebe Getahun ${ }^{1}$, Zeleke Bereie ${ }^{2 *}$ and Eshetie Dejen ${ }^{3}$ \\ ${ }^{1}$ Addis Ababa University, Ethiopia \\ ${ }^{2}$ Gilgel Belese teacher's college, Bahir Dar, Ethiopia \\ ${ }^{3}$ Amhara Regional Agricultural Research Institute, P.O. Box 794, Bahir Dar, Ethiopia
}

Received: 26 March, 2020

Accepted: 04 July, 2020

Published: 06 July, 2020

*Corresponding author: Zeleke Bereie, Gilgel Belese teacher's college, Bahir Dar, Ethiopia,

E-mail: zelekeml@yahoo.com

Keywords: Rivers; Beles; Gilgel Beles; Diversity

https://www.peertechz.com

\section{Check for updates}

\begin{abstract}
Diversity of fish species of Beles and Gilgel Beles Rivers were studied. Fishes were sampled using gill nets of various stretched mesh sizes, and hooks and lines. Identification of fish was made to species level by comparing the sample characters with taxonomic keys found in literatures and specimens deposited. Shannon diversity index $\left(\mathrm{H}^{\prime}\right)$ was used to evaluate species diversity of fishes. A total of 1124 individual fishes belonging to 5 orders, 7 families, 13 genera and 23 species were caught in Beles and Gilgel Beles Rivers. Cyprinidae was best-represented family with the highest number of fish species in the rivers while Labeo and Labeobarbus were the bestrepresented genera. A higher number of species were recorded in the Beles River (22 species) than in the Gilgel Beles River (5 species). The diversity index was higher in the Beles River $\left(H^{\prime}=2.43\right)$ than in the Gilgel Beles River $\left(H^{\prime}=0.88\right)$. In general, Beles River is richer than Gilgel Beles River, in terms of total numbers of fish caught and number of species recorded. In order to have a better knowledge of the fish populations in the study area, further studies are required on diversity, abundance and biology of the fishes. Therefore, sustainable utilization and conservation measures should be taken in the two rivers.
\end{abstract}

\section{Introduction}

Species diversity and abundance reflect the quantity and quality of the available habitat. The decline in abundance of freshwater fish in the world has been of concern for over one hundred years. Since the twentieth century, many fish species have suffered continuing declines in abundance and distribution, some at alarming levels. This includes many of the smaller species as well as all of the species targeted by inland commercial and recreational fisheries. These declines in abundance are commonly attributed to factors such as general habitat degradation [1], modified patterns of stream flow [2], interrupted migratory pathways [3], reduced water quality and pollution [4], introduction of alien fish and diseases [5], illegal fishing and commercial over fishing [6] and altered biotic interactions [7].

As in many parts of the world, population growth, agricultural development and industrialization contribute to the loss of species diversity of freshwater fishes in Ethiopia [8]. Wide spread deforestation, degradation of the pristine environment, and other human induced factors might have left many Ethiopian streams, specially the northern ones, devoid of fish but the apparently resilient cyprinids [8]. As in many parts of the Ethiopia, human activities degrade fish habitat in numerous ways in study area. Wild fire, logging, impoundment, canalisation and agricultural activities are some of the major activities that degrade fish habitat. At present, we have no evidence of species extinction from Ethiopian freshwaters (Harrison and Stiassny, undated cited in Abebe Getahun and Stiassny, 1998) resulting from degradation of environment. One of the main reasons is a lack of definitive information on diversity of freshwater fishes and inconclusive data on the freshwater fish species.

Beles and Gilgel Beles Rivers are flowing to the lower course of Abay in which adequate attention has not been given in the study of the diversity, abundance and economical potential 
of the fish fauna due to the presence of some inaccessible mountains and rugged geographical features. The absence of fishery data on these rivers triggers the researcher to conduct this study. Therefore, the study attempted to identify species composition of fishes in Beles and Gilgel Beles Rivers and evaluate the species diversity of Beles and Gilgel Beles Rivers fishes.

\section{Materials and methods}

Site selection: - A reconnaissance survey was conducted together with the research advisor to fix sampling sites. The survey was conducted in four sub areas along the Beles and Gilgel Beles Rivers. Two sampling sites were selected from each river taking into consideration the velocity of water, habitat type, altitude, depth of water, vicinity to road and substrate type Table 1, Figure 1.

Fieldwork: - Three surveys were conducted to collect specimens from the sampling sites. The samples were taken in November, March and May. November and May were wet months while March was dry month. Gill nets with different mesh sizes were used to collect fishes. Multiple hooks and

Table 1: Estimated distances from Gilgel Beles at Mender hullet, altitude and coordinates of sampling sites.

\begin{tabular}{|c|c|c|c|c|}
\hline Site & Code & $\begin{array}{c}\text { Distance from } \\
\text { Mh }\end{array}$ & $\begin{array}{l}\text { Elevation } \\
\text { (a.s.l) }\end{array}$ & Coordinate (GPS) \\
\hline $\begin{array}{l}\text { Gilgel Beles } \\
\text { at Mender hullet }\end{array}$ & $\mathrm{Mh}$ & - & $1011 \mathrm{~m}$ & $\begin{array}{c}11^{\circ} 09^{\prime} 53.5^{\prime \prime} \mathrm{N} ; 36^{\circ} 20^{\prime} \\
39.3^{\prime \prime} \mathrm{E}\end{array}$ \\
\hline $\begin{array}{l}\text { Gilgel Beles } \\
\text { at College }\end{array}$ & Coll & $2 \mathrm{~km}$ & 1007 m & $\begin{array}{c}11^{\circ} 09^{\prime} 35.1^{\prime \prime} \mathrm{N} \\
36^{\circ} 20^{\prime} 008^{\prime \prime} \mathrm{E}\end{array}$ \\
\hline Beles at bridge & BB & $6 \mathrm{~km}$ & $994 \mathrm{~m}$ & $\begin{array}{l}11^{\circ} 11^{\prime} 56.7^{\prime \prime} \mathrm{N} ; \\
36^{\circ} 19^{\prime} 31.7^{\prime \prime} \mathrm{E}\end{array}$ \\
\hline $\begin{array}{c}\text { Beles at } \\
\text { Babizenda }\end{array}$ & BAB & 156 km & $596 \mathrm{~m}$ & $\begin{array}{l}11^{\circ} 07^{\prime} 54.8^{\prime \prime} \mathrm{N} ; \\
35^{\circ} 28^{\prime} 13.6^{\prime \prime} \mathrm{E}\end{array}$ \\
\hline
\end{tabular}

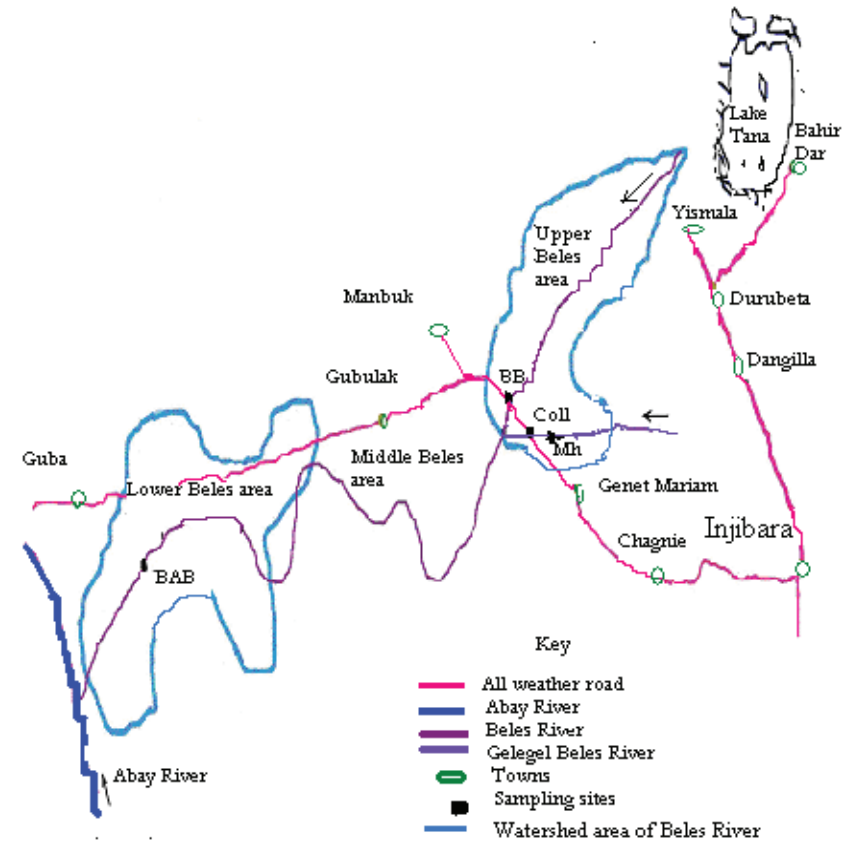

Figure 1: Map of Beles and Gilgel Beles Rivers (un scaled) (FDROE, MOWR, 2000). lines were used in areas where gill nets were not suitable. Immediately after retrieval, fishes were removed and total length and total weight of each specimen were measured. Total length was measured to the nearest $0.1 \mathrm{~cm}$.

Laboratory studies: - The specimens were soaked in tap water for a week to wash the formalin from the specimens. Then, they were transferred to $75 \%$ ethanol. Identification was made to species level by comparing the sample characters with taxonomic keys found in the literature and specimens deposited at the Fisheries Laboratory, Department of Biology, AAU, and also at Bahir Dar fisheries and other aquatic life Research Center, and at National Fisheries and Other Living Aquatic Resources Research Centre, Sebeta. Keys found in Shibru Tedla [9], Boulenger [10-13], Lévêque et al. [14,15], Eschemeyer [16], Nagelkerke [17], Bishai and Khalil [18] and Golubtsov, et al. [19], were used for identification. Meristic and morphometric characters were assessed for comparison purpose.

\section{Data analysis}

Generally, SPSS for Windows (version 10) and MINITAB (version 14) were used to perform the calculations and statistical analysis. Shannon diversity index $\left(\mathrm{H}^{\prime}\right)$ was used to evaluate species diversity of fishes. The Shannon index of diversity $\left(\mathrm{H}^{\prime}\right)$ is a measure of the number of species weighted by their relative abundances (Begon et al. 1990). The Shannon's diversity index explains both the variety and the relative abundance of species (Næsje et al., 2004). $\mathrm{H}^{\prime}$ was calculated as:

$\mathrm{H}^{\prime}=-\Sigma$ pi ln pi

Where, pi is the proportion of individuals found in the ith species. Shannon's diversity index ( $\left.\mathrm{H}^{\prime \prime}\right)$ was used to indicate diversity at different sampling sites and/or rivers. A high value indicates high species diversity. Significance of differences in species diversity between sampling sites and/or rivers was tested using $\mathrm{T}$-test.

\section{Results and discussion}

\section{Fish species composition of beles and gilgel beles rivers}

A total of 23 fish species were recorded during the present study from Beles and Gilgel Beles Rivers (Table 2). These fishes were represented by a single class Actinopterygii (rayfinned fishes), seven families and five orders (Table 2). The Cyprinidae, Bagridae and Characidae were the best-represented families with respect to numbers of species; with 11, 3 and 3 species, respectively (Table 2). Labeo and Labeobarbus were the best-represented genera with numbers of species; with five and four species, respectively (Table 2). The freshwater fish fauna of Beles and Gilgel Beles Rivers contain a mixture of Nilo Sudanic (e.g. B. docmak, B. bajad, H. forskhalii, L. forskalii, M. kannume, S. serratus and S. schall ), highland East African (e.g. L. intermedius, L. nedgia, C. gariepinus and O. niloticus) and Endemic forms ( e.g. V. beso).

\section{Species diversity}

A higher number of species were recorded in the Beles River (22 species) than in the Gilgel Beles River ( 5 species) in 
the present study (Table 3). The number of fish species was highest at BAB and lowest at Mh sites (Table 3). Cyprinidae was the best-represented family with the highest number of fish species both in the Gilgel Beles and Beles Rivers. Although there was a pronounced disparity in species composition between Beles and Gilgel Beles Rivers, there was an overlap in L. forskalii, L. nedgia, L. intermedius and O. niloticus in the present study. However, V. beso, which is found in Gilgel Beles

Table 2: Fish species composition of Beles and Gilgel Beles Rivers.

\begin{tabular}{|c|c|c|c|}
\hline Species name & $\begin{array}{c}\text { Common name } \\
\text { (Gumuz) }\end{array}$ & Family & Order \\
\hline R. loati Boulenger 1901 & Abella & \multirow{11}{*}{ Cyprinidae } & \multirow{11}{*}{ Cypriniformes } \\
\hline V. beso & - & & \\
\hline L. niloticus & Tsemebebella & & \\
\hline L. horie & - & & \\
\hline L. coubie & - & & \\
\hline L. forskalii & Tseya & & \\
\hline L. cylindricus & - & & \\
\hline L. bynni Boulenger 1911 & Goshe & & \\
\hline L. intermedius & - & & \\
\hline L. nedgia Rüppell 1836 & - & & \\
\hline L. degeni Boulenger 1902 & & & \\
\hline C. gariepinus & - & \multirow[b]{2}{*}{ Clariidae } & \multirow{7}{*}{ Siluriformes } \\
\hline $\begin{array}{l}\text { H. longifilis } \\
\text { Valenciennes } 1840\end{array}$ & & & \\
\hline B. bajad & - & \multirow[t]{3}{*}{ Bagridae } & \\
\hline B. docmak & - & & \\
\hline A. occidentalis & Jajuma & & \\
\hline S. serratus & - & \multirow{2}{*}{ Mochokidae } & \\
\hline S. schall & Buwa & & \\
\hline H. forskhalii & - & \multirow{3}{*}{ Characidae } & \multirow{3}{*}{ Characiformes } \\
\hline B. macrolepidotus & Yechacheya & & \\
\hline B. nurse Rüppell 1832 & Lekewar & & \\
\hline M. kannume & Bebela & Mormyridae & Osteoglossiformes \\
\hline O. niloticus & Begebella & Cichlidae & Perciformes \\
\hline
\end{tabular}

Table 3: Species composition of Beles and Gilgel Beles Rivers (+ = present; - absent).

\begin{tabular}{|l|c|c|c|c|c|c|}
\hline \multirow{2}{*}{\multicolumn{1}{c}{ Species }} & \multicolumn{3}{c}{ Sampling sites } & & Rivers & \\
\cline { 2 - 7 } & Mh & Coll & BB & BAB & G.Beles & Beles \\
\hline R. loati & - & - & + & + & - & + \\
\hline V. beso & + & + & - & - & + & - \\
\hline L. niloticus & - & - & - & + & - & + \\
\hline L. horie & - & - & - & + & - & + \\
\hline L. coubie & - & - & - & + & - & + \\
\hline L. forskalii & + & + & + & + & + & + \\
\hline L. cylindricus & - & - & + & + & - & + \\
\hline L. bynni & - & - & + & + & - & + \\
\hline L. intermedius & + & + & + & - & + & + \\
\hline L. nedgia & + & + & + & + & + & + \\
\hline L. degeni & - & - & + & + & - & + \\
\hline C. gariepinus & - & - & - & + & - & + \\
\hline H. longifilis & - & - & - & + & - & + \\
\hline B. bajad & - & - & - & + & - & + \\
\hline B. docmak & - & - & + & + & - & + \\
\hline A. occidentalis & - & - & - & + & - & + \\
\hline S. serratus & - & - & - & + & - & + \\
\hline S. schall & - & - & + & + & - & + \\
\hline H. forskhali & - & - & - & + & - & + \\
\hline B. macrolepidotus & - & - & + & + & - & + \\
\hline B. nurse & - & - & - & + & - & + \\
\hline M. kannume & - & - & + & + & - & + \\
\hline O. niloticus & - & + & - & + & + & + \\
\hline
\end{tabular}

River, was not found in Beles River. Thus, large incidence of Gilgel Beles fishes in Beles River is due to drainage connection between the two rivers. Although several fish collections have been made from the Blue Nile system, few reports of collections are available from Gilgel Beles and Beles Rivers. Fish surveys which were carried out in the Gilgel Beles and Beles Rivers by JERBE and $2000[20,21]$, respectively were comparable to the present study. Compared to Sanja, WabiShebele and Angereb Rivers, Beles River harbors more diverse fish fauna. Sanja, WabiShebele and Angereb Rivers harbor 8, 13 and 19 fishes, respectively [22-24]. How ever, fish species diversity of Beles River comparable to Alvero River (31), a tributary of Baro, in the lowland Gambela region [25].

The species list obtained in the present study reveal a difference in number of species between Beles and Gilgel Beles Rivers, as it was also shown by the species list of JERBE [20,21]. However, there was some difference in species composition between the present study and that of JERBE [20,21]. Most of the species recorded during the present study in the Gilgel Beles and Beles Rivers were also recorded by JERBE surveys. Although JERBE [21] listed 25 fish species from Beles River, the following seven species were recorded during the present study but were not listed by JERBE [21]: H. forskhali, C. gariepinus, H. longifilis, B. nurse, A. occidentalis, R. loati and L. bynni. Some species that were found by JERBE [20], from Beles River were not found by the present study. These were Mormyrops anguilloides Linnaeus 1758, Mormyrus caschive Linnaeus 1758, M. hasselquistii, Micralestes acutidens Daget 1957, Distichodus engycephalus, Chelaethiops bibie, Garra sp., Leptocypris niloticus, Schilbe mystus, Chiloglanis sp., and Tetraodon lineatus. JERBE [20] listed four fish species from Gilgel Beles River. L. forskalii is recorded in the present study from Gilgel Beles River but not JERBE [20]. However, Garra sp. was recorded by JERBE [20], from Gilgel Beles River but not in the present study.

Differences seen in the species composition between the present study and that of JERBE $[20,21]$, might be due to differences in the sampling efficiency, habitats and seasons. The higher number of species recorded by JERBE might be attributed to the flexibility of their gears. In addition, many of their gears can be classified as active gears, in contrast to the gill nets and multiple hooks and lines of present study. Compared to JERBE surveys, a wider range of habitats and months were sampled in the present study. This might be a reason for some species that caught in the Present study that were not reported by JERBE.

Species diversity, according to $\mathrm{H}^{\prime}$, was higher in the Beles River $\left(H^{\prime}=2.42\right)$ than in the Gilgel Beles River $\left(H^{\prime}=0.88\right)$ for the total catch (Table 4). Among sampling sites, species diversity was highest at Babizenda $\left(\mathrm{H}^{\prime}=2.3\right)$ and lowest at College $\left(\mathrm{H}^{\prime}=\right.$ 0.77) (Table 4).

The number of fish species ranged from 6 to 19 with a mean \pm SD of $11.2+5.26$ in Beles River and it ranged 3 to 4 with a mean \pm SD of $3.67+0.82$ in Gilgel Beles River. Shannon diversity index ranged 1.67 to 2.6 with a mean \pm SD of $1.81+0.52$ in Beles River and it ranged 0.46 to 1.04 with a mean \pm SD of $0.73+0.2$ in 
Gilgel Beles River. There was significant variation in both mean number of fish species and diversity index between Beles and Gilgel Beles Rivers $(\mathrm{P}<0.05)$ (Table 5).

Table 4: Number of species $(\mathrm{N})$ and diversity index $\left(\mathrm{H}^{\prime}\right)$ for total catch at sampling sites and rivers.

\begin{tabular}{|c|c|c|c|c|c|c|}
\hline & \multicolumn{5}{|c|}{ Sampling sites } & vers \\
\hline & Mh & Coll & BB & BAB & $\begin{array}{l}\text { Gilgel } \\
\text { Beles }\end{array}$ & Beles \\
\hline $\mathrm{H}^{\prime}$ & 1.08 & 0.77 & 1.82 & 2.3 & 0.88 & 2.42 \\
\hline$N$ & 4 & 5 & 12 & 21 & 5 & 22 \\
\hline
\end{tabular}

Table 5: Mean number of species $(\mathrm{N})$ and diversity indices $\left(\mathrm{H}^{\prime}\right)$ for fish caught in Beles and Gilgel Beles Rivers.

\begin{tabular}{|c|c|c|c|c|c|}
\hline$H^{\prime} / N$ & River & Mean+ SD & $\mathbf{t}$ & df & Sig. \\
\hline \multirow{2}{*}{$\mathrm{H}^{\prime}$} & Gilgel Beles & $0.73 \pm 0.2$ & \multirow{2}{*}{4.71} & \multirow{2}{*}{9} & \multirow{2}{*}{0} \\
\hline & Beles & $1.81 \pm 0.52$ & & & \\
\hline \multirow{2}{*}{$\mathrm{N}$} & Gilgel Beles & $3.67 \pm 0.82$ & \multirow{2}{*}{3.49} & \multirow{2}{*}{9} & \multirow{2}{*}{0.01} \\
\hline & Beles & $11.2 \pm 5.26$ & & & \\
\hline
\end{tabular}

Biodiversity patterns are directly and indirectly influenced by the geomorphology of riverine landscapes, which may be perceived as a nested hierarchy . The number of fish species in Beles and Gilgel Beles Rivers appear to be negatively correlated with altitude. The increase in number of fish species from $\mathrm{Mh}$ to BAB sampling sites coincide with decline in elevation. The main pattern documented in this study, is the occurrence of a distinct headwater fauna, and a sequential down stream shift in species composition. The decrease in number of fish species from lower to upper reaches were consistent with the studies carried out in other areas by Nikolsky [26], Sydenham [27] and Golubtsov and Mina [28]. The increase in species number from up stream sites to down stream sites was associated with change in catchment area, canopy closure, substrate type, distance from source, depth and width of rivers [29]. These variables reflect longitudinal gradient in the study area. Width of river was the most important variable that coincided with increase in species number from $\mathrm{Mh}$ sites to $\mathrm{BAB}$ sites. A total of 21 fish species found in Beles River at $B A B$ sampling site with its mean river width of $56.5+2.12 \mathrm{~m}$ while the lowest number of species (4) in Gilgel Beles River at Mh sampling site with its mean river width of $31+2 \mathrm{~m}$. This result is consistent with the studies carried out in other areas. In tropical area as Angermerier and Karr (1983) in Panama, EDDS [30] in India and Toham and Teugels [29] in Cameroon found respectively a significant relation ship between species number and width of the river, and species number and increasing gradient of depth A total of 12 fish species found in Beles River at BB sampling site with its mean river depth of $6.3+0.5 \mathrm{~m}$ while the lowest number of species (4) in Gilgel Beles River at Mh sampling site with its mean river width of rive $2.42+0.28 \mathrm{~m}$. A similar result using depth gradient [31], stream order or river position in the gradient [32-36], have also been reported for temperate rivers. In addition, canopy closure and diversity of substrate type (sand, gravel and large rocks) were also most probable environmental gradient explaining the spatial distribution of species in the sampling sites. Thus, the presence of year round dense vegetation and higher catchment area, diversity of substrate, river depth and width might contribute to high species diversity in Beles River than in Gilgel Beles.

\section{Species diversity during wet and dry seasons}

A higher number of species was recorded in the dry than in the wet season in total catch ( 22 versus 18 species) (Table 5). R. loati, V.beso, L. niloticus, L. forskalii, L. horie, L. bynni, L. intermedius, L. nedgia, L. degeni, B. docmak, B. macrolepidotus, B. nurse, A. occidentalis, S. serratus, S. schall, $M$. kannume and $\mathrm{O}$. niloticus were found both during wet and dry seasons in total catch. L. coubie, C. gariepinus, B. bajad, $\mathrm{H}$. longifilis and $\mathrm{H}$. forskhalii were collected during dry season where as Labeo cylindricus was collected during wet season. There was no pronounced disparity in the species composition between wet and dry seasons in Gilgel Beles River (Table 6). However, there was marked difference in species composition during wet and dry seasons in Beles River (Table 6).

The value of Shannon's diversity index was 0.81 and 0.66 in dry and wet seasons in Gilgel Beles River, respectively (Table 6). The index was also higher in the dry $\left(\mathrm{H}^{\prime}=2.48\right)$ than wet season $\left(\mathrm{H}^{\prime}=2.21\right)$ in Beles River (Table 6). Shannon's diversity index $\left(\mathrm{H}^{\prime}\right)$ indicated that species diversity was higher in dry than wet season in each river. The species diversity was also higher in the dry $\left(\mathrm{H}^{\prime}=2.29\right)$ than wet season $\left(\mathrm{H}^{\prime}=1.99\right)$ for the total catch (Table 6). The highest species diversity was obtained in Beles River during dry season $\left(\mathrm{H}^{\prime}=2.48\right)$ while the lowest in Gilgel Beles River during wet season $\left(\mathrm{H}^{\prime}=0.66\right)$ (Table 6$)$.

Table 6: Number of species $(\mathrm{N})$ and diversity index $\left(\mathrm{H}^{\prime}\right)$ for fish caught during wet and dry seasons.

\begin{tabular}{|c|c|c|c|c|c|c|}
\hline River & \multicolumn{2}{|c|}{ Gilgel Beles } & \multicolumn{2}{|c|}{ Beles } & \multicolumn{2}{|c|}{ Beles and Gilgel Beles } \\
\hline Season & Dry & Wet & Dry & Wet & Dry & Wet \\
\hline H' $^{\prime}$ & 0.81 & 0.66 & 2.48 & 2.21 & 2.29 & 1.99 \\
\hline N & 4 & 5 & 19 & 17 & 22 & 18 \\
\hline
\end{tabular}

The number of fish species ranged from 3 to 14 with a mean \pm SD of $6.57+4.04$ in wet seasons in Beles and Gilgel Beles Rivers and it ranged 3 to 19 with a mean \pm SD of $8+7.44$ in dry season. Shannon diversity index ranged from 0.46 to 1.99 with a mean \pm SD of $1.16+0.59$ in wet season in Beles and Gilgel Beles Rivers and it ranged 0.75 to 2.6 with a mean \pm SD of 1.33 +0.88 in dry season. There was significant difference in the mean number of fish species and diversity index between Beles and Gilgel Beles Rivers both in wet and dry seasons $(\mathrm{P}<0.05)$ (Table 7). However, there was no significant difference in the mean number of fish species and diversity indices between wet and dry seasons in the total catch $(\mathrm{P}>0.05)$ (Table 7).

There might be several reasons for changes in catches between wet and dry seasons. For example, variation in available habitats and gill net efficiency might contribute to variations in the catches. The higher number of species recorded during dry season than wet season attributed to a wider range of habitats sampled. This was mainly due to habitats suitable for gill net sampling during dry season. However, during wet season trees that grow hanging their branches down to the water on either 
Table 7: Mean number of fish species $(\mathrm{N})$ and diversity index $\left(\mathrm{H}^{\prime}\right)$ during wet and dry seasons.

\begin{tabular}{|c|c|c|c|c|c|c|}
\hline $\mathrm{H}^{\prime} / \mathrm{N}$ & Season & River & Mean \pm SD. & $\mathbf{t}$ & df & Sig. \\
\hline \multirow{2}{*}{$\mathrm{H}^{\prime}$} & Wet & Beles \& G. Beles & $1.16 \pm 0.59$ & \multirow{2}{*}{0.39} & \multirow{2}{*}{9} & \multirow{2}{*}{0.7} \\
\hline & Dry & Beles \& G. Beles & $1.33 \pm 0.88$ & & & \\
\hline \multirow{2}{*}{$\mathrm{N}$} & Wet & Beles \& G. Beles & $6.57 \pm 4.04$ & \multirow{2}{*}{0.42} & \multirow{2}{*}{9} & \multirow{2}{*}{0.68} \\
\hline & Dry & Beles \& G. Beles & $8 \pm 7.44$ & & & \\
\hline \multirow{2}{*}{$\mathrm{H}^{\prime}$} & Wet & Gilgel Beles & $0.72 \pm 0.24$ & \multirow{2}{*}{5.82} & \multirow{2}{*}{5} & \multirow{2}{*}{0} \\
\hline & Wet & Beles & $1.75 \pm 0.21$ & & & \\
\hline \multirow{2}{*}{$\mathrm{N}$} & Wet & Gilgel Beles & $3.75 \pm 0.96$ & \multirow{2}{*}{3.98} & \multirow{2}{*}{5} & \multirow{2}{*}{0.01} \\
\hline & Wet & Beles & $10.33 \pm 3.21$ & & & \\
\hline \multirow[t]{2}{*}{$\mathrm{H}^{\prime}$} & Dry & Gilgel Beles & $0.76 \pm 0.14$ & \multirow{2}{*}{3.98} & \multirow{2}{*}{5} & \multirow{2}{*}{0.01} \\
\hline & Dry & Beles & $1.91+0.98$ & & & \\
\hline \multirow{2}{*}{$\mathrm{N}$} & Dry & Gilgel Beles & $3.5 \pm 0.71$ & \multirow{2}{*}{5.82} & \multirow{2}{*}{5} & \multirow{2}{*}{0} \\
\hline & Dry & Beles & $12.5 \pm 9.19$ & & & \\
\hline
\end{tabular}

side of the riverbank hinder reaching residency of fish in their habitats. Habitats targeted to gill nets were seldom deep water areas where some fish often reside dislocated by current of rivers during wet seasons. In addition, during wet season the efficiency of gill nets were decreased by logs, leaves, roots etc that were brought by flooding into rivers. Thus, differences seen in the data between wet and dry season may be due to differences in available habitats and gill net efficiency.

\section{Conclusions and recommendations}

\section{Conclusions}

Beles River is richer than Gilgel Beles River, in terms of both total numbers of fish caught and numbers of species recorded. A higher number of species were recorded in the Beles River (22 species) than in the Gilgel Beles River ( 5 species) in the present study. The increase in number of fish species from lower to upper reaches of study area coincide with decline in elevation.

The Cyprinidae, Bagridae and Characidae were the bestrepresented families with respect to numbers of species; with 11, 3 and 3 species, respectively. The Labeo and Labeobarbus were the best-represented genera with numbers of species. L. nedgia and L. degeni considered belonging to a single lip morphotype (Labeobarbus nedgia) endemic to Lake Tana by Nagelkerke and Sibbing (1996) are found in Beles River.

The species diversity was also higher in the Beles River $\left(\mathrm{H}^{\prime}=\right.$ 2.42) than in the Gilgel Beles River $\left(\mathrm{H}^{\prime}=0.88\right)$ for total catch. A higher number of species was recorded in dry than wet season in total catch (22 versus 18 species). The species diversity was also higher in the dry $\left(\mathrm{H}^{\prime}=2.29\right)$ than wet season $\left(\mathrm{H}^{\prime}=1.99\right)$ for the total catch.

\section{Recommendation}

In order to have a better knowledge of the fish populations detailed studies and investigations are required on diversity and abundance of fish species in Abay basin in general and in Beles and Gilgel Beles Rivers in particular, especially at the lower reaches of Beles River. In addition, detailed knowledge on the biology and behaviour of most of the species are still lacking. Therefore, further studies are required on the biology and behaviour of fishes in the study area.

\section{Acknowledgment}

Lastely,I thank Graduate and Research Program of Addis Ababa University for financial support and Amhara Regional Agricultural Research Institute (ARARI) through its Bahir Dar FOALRC for their assistance all logistic necessities for fieldwork.

\section{References}

1. Llewellyn LC (1983) The distribution of Fish in New South Wales. Australian Society for Limnology, Special Publication 23. Link: https://bit.ly/3e1tGXs

2. Gehrke PC, Brown P, Schiller CB, Moffatt DB, Bruce AM (1995) River regulation and fish communities in the Murray - Darling River system, Australia. Regulated Rivers: Research and Management 11: 363 -375. Link: https://bit.ly/206GyBn

3. Mallen-Cooper M, Stuart I, Hides-Pearson F, Harris J (1995) Fish migration in the Murray River and assessment of the Torrumbarry fishway: New South Wales Fisheries Research Institute, Sydney.

4. Koehn J, O'Connor W (1990) Threats to Victorian native freshwater fish Victorian Naturalist 107: 5-12.

5. Cooper M, Harris JH (1993) Fish migration in the Murray Darling system and the decline of the Silver Perch. Australian Government Publishing Service, Canberra 41.

6. Brown P (1992) The Murrumbidgee River fishery: a historical perspective. In Roberts $\mathrm{J}$ and Oliver R (eds.). The Murrumbidgee, past and present, 20-26. CSIRO, Griffith

7. Schiller CB, Bruce AM, Gehrke PC (1997) Distribution and abundance of native fish in New South Wales Rivers. In: Harris, J.H. and Gehrke, P.C. (Eds). "Fish and rivers in stress: The NSW rivers survey", 71-102. New South Wales Fisheries Office of Conservation and the Cooperative Research Centre for Freshwater Ecology.

8. Getahun A, Stiassny MLJ (1998) The Fresh water Biodiversity crisis: the case of the Ethiopian fish fauna. SINET: Ethiop J Sci 21: 207-230. Link: https://bit.ly/31MvT6H

9. Tedla S (1973) Fresh water fishes of Ethiopia. Haile Selassie University, Dept of Biology, Addis Ababa, Ethiopia. 107.

10. Boulenger GA (1909) Catalogue of the fresh water fishes of Africa.Vol. I. British Museum (Natural History), London, 373. Link: https://bit.ly/2BBduz6

11. Boulenger GA (1911) Catalogue of the fresh water fishes of Africa. Vol. II. British Museum (Natural History), London, 529. Link: https://bit.ly/2BBduz6

12. Boulenger GA (1915) Catalogue of the fresh water fishes of Africa. Vol.III. British Museum (Natural History), London, 526. Link: https://bit.ly/2BBduz6

13. Boulenger GA (1916) Catalogue of the fresh water fishes of Africa. Vol.IV. British Museum (Natural History), London, 392. Link: https://bit.ly/2BBduz6

14. Lévêque C, Paugy D, Teugels GG (1990) The Fresh and Brackish water fishes of West Africa. Paris, France 1: 386.

15. Lévêque C, Paugy D, Teugels GG (1992) The Fresh and Brackish water fishes of West Africa. Paris, France 2: 521.

16. Eschmeyer WN (2006) Catalog of fishes. California Academy of Sciences. Link: https://bit.ly/3gqogXL

17. Nagelkerke LAJ (1997) The barbs of Lake Tana, Ethiopia - morphological diversity and its implication for taxonomy, trophic resource partitioning, and fisheries. Ph.D. thesis, Wageningen University. Link: https://bit.ly/2AxnbhA

18. Bishai MH, Khalil TM (1997) Fresh water fishes of Egypt. Puplication of National Biodiversity Unit 229. Link: https://bit.ly/2CZxpbd 
19. Golubstov AS, Darkov AA, Dgebuadze Yu, Mina MV (1995) An Artificial key to fish species of the Gambela region (The White Nile basin in the limits of Ethiopia). Joint Ethio-Russian Biological Expedition, Addis Ababa, Ethiopia. 84. Link: https://bit.ly/2Zv0m6A

20. JERBE (1999) Report on the studies carried out by the freshwater biology group of the joint Ethio - Russian biological expedition.

21. JERBE (2000) Report on the studies carried out by the freshwater biology group of the joint Ethio-Russian biological expedition.

22. Genanew Tesfaye (2006) Diversity, relative abundance and biology of fishes in Angereb and Sanja Rivers, Tekeze basin, Ethiopia. M. Sc.Thesis, Addis Ababa University, Ethiopia 89. Link: https://bit.ly/3ita8P8

23. JERBE (2004) Report on the studies carried out by the freshwater biology group of the joint ethio-russian biological expedition.

24. JERBE (2005) Report on the studies carried out by the freshwater biology group of the joint ethio-russian biological expedition.

25. JERBE (2001) Report on the studies carried out by the freshwater biology group of the joint ethio-russian biological expedition.

26. Nikolsky GV (1963) The Ecology of fishes. Academic Press, London and New York. 352. Link: https://bit.ly/3is785G

27. Sydenham DHJ (1977) The qualitative composition and longitudinal zonation of the fish fauna of the River Ogun, Western Nigeria. Revue de Zoologie Africanes 91: 974-996.

28. Golubtsov AS, Mina MV (2003) Fish species diversity in the main drainage systems of Ethiopia: current state of knowledge and research perspectives. Ethiop J Natu Reso 5: 281-318. Link: https://bit.ly/3imYdT0

29. Andre Kandem T, Teugels G (1998) Diversity pattern of fish assemblages in the lower Ntem River basin (Cameroon), with notes on potential effects of deforestation. Arch Hydrobiology 141: 421-446. Link: https://bit.ly/2ZybOOV

30. EDDS DR (1993) Fish assemblage structure and environmental correlates in Nepal's Gandaki River. Copeia 1: 48 - 60. Link: https://bit.ly/3goK1qP

31. Sheldon AL (1968) Species diversity and longitudinal succession in stream fishes. Ecology 49:193-198. Link: https://bit.ly/31lhBUx

32. Beecher HA, Dott ER, Fernaw RF (1988) Fish species richness and stream order in Washington streams. Environ Biol Fish 22: 193 - 209. Link: https://bit.ly/3iwS4DN

33. Oberdorff T, Porcher JP (1992) Fish assemblage structure in Brittany streams (France). Aqua Living Resour 5: 215-223.

34. Oberdorff T, Guibert E, Lucetta JU (1993) Patterns of fish species richness in the seine river basin, France. Hydrobiologia 259: 157-169. Link: https://bit.ly/3eZnOKL

35. Wudneh T (1998) Biology and management of fish stock in Bahir Dar gulf, Lake Tana, Ethiopia. PhD Thesis, Wageningen Agricultural University, Wageningen143. Link: https://bit.ly/31PRY4w

36. Wood RB, Talling JF (1988) Chemical and algal relationships and salinity series of Ethiopian inland waters. Hydrobiologia 158: 29-67. Link: https://bit. ly/38sYa3E
Discover a bigger Impact and Visibility of your article publication with

Peertechz Publications
Highlights

* Signatory publisher of ORCID

* Signatory Publisher of DORA (San Francisco Declaration on Research Assessment)

* Articles archived in worlds' renowned service providers such as Portico, CNKI, AGRIS, TDNet, Base (Bielefeld University Library), CrossRef, Scilit, J-Gate etc.

- Journals indexed in ICMJE, SHERPA/ROMEO, Google Scholar etc.

* OAI-PMH (Open Archives Initiative Protocol for Metadata Harvesting)

* Dedicated Editorial Board for every journal

* Accurate and rapid peer-review process

* Increased citations of published articles through promotions

* Reduced timeline for article publication

Submit your articles and experience a new surge in publication services (https://www.peertechz.com/submission).

Copyright: @ 2020 Getahun A, et al. This is an open-access article distributed under the terms of the Creative Commons Attribution License, which permits unrestricted use distribution, and reproduction in any medium, provided the original author and source are credited

Citation: Getahun A, Bereie Z, Dejen E (2020) Diversity of fishes in Beles and Gilgel beles Rivers, abay basin, Ethiopia. Int J Aquac Fish Sci 6(3): 068-073. DOI: https:// dx.doi.org/10.17352/2455-8400.000059 